\title{
Is the Public Willing to Help the Nigerian Police During the Boko Haram Crisis? A Look at Moderating Factors
}

\author{
Stamatis Elntib $^{1} \cdot$ Zainab Sani Nass $^{1} \cdot$ Maria Ioannou $^{2} \cdot$ Saskia Ryan $^{2} \cdot$ \\ Paul Christiansen ${ }^{1}$
}

Published online: 21 March 2017

(C) The Author(s) 2017. This article is published with open access at Springerlink.com

\begin{abstract}
This paper sought the opinion of 200 Nigerians on their willingness to cooperate with the police during the Boko Haram crisis. Public perceptions of police effectiveness during the crisis, residence location, gender and religious affiliation were used as moderators. Data was analysed using an explanatory factor analysis and structural equation modelling. Results indicated a strong association between perceived effectiveness and willingness to report to the police with respondents who question the effectiveness of the police being less likely to be willing to report criminal activity about Boko Haram. Further to this, the impact of religion on willingness to report was at least partially mediated by perceived effectiveness of the police with the results showing that Christian respondents perceived the police as less effective. Females and those living in the north were significantly less willing to report criminal activity to the police. The findings are discussed in relation to the $\mathrm{BH}$ crises and directions for future research are given.
\end{abstract}

Keywords Boko Haram · Police effectiveness · Religious extremism - Willingness to help the police

Laureate Online Education B.V. is in partnership with the University of Liverpool.

Stamatis Elntib

stamatis.eldib@online.liverpool.ac.uk

Zainab Sani Nass

zeenasesq@yahoo.com

Maria Ioannou

m.ioannou@hud.ac.uk

Saskia Ryan

Saskia.Ryan@hud.ac.uk

\section{Introduction}

The Boko Haram (BH) belligerency in northern Nigeria erupted in 2009 as retaliation for the extra-judicial killing of their leader, Muhammed Yusuf. It started with a series of bombings and gun attacks on police stations, government agencies, international organisations, schools, liquor houses, and media houses (Agbiboa, 2013; Murtada, 2013). At present however, targets are primarily the general public, Muslim clerics, and traditional leaders (Agbiboa, 2013; Anyadike, 2013). Their strategic change in selecting their victims questions their objectives for the attacks (Anyadike, 2013; Chukwuma and Philip, 2014) and adds to the ambiguity surrounding their ultimate purpose of existence. A new dimension to the extremist organisation surfaced on April 14, 2014 when $\mathrm{BH}$ abducted 276 teenage girls from a secondary school in Chibok, Borno State (Akinloye, 2014). It took tremendous pressure from the international community, social groups, and the media for the government to respond (Hassan, 2014). The Chibok abduction became a major crisis for the government; yet most of the girls remain captured and negotiations for their release are still ongoing (World Watch Monitor, 2017) and

Paul Christiansen

Paul.Christiansen@liverpool.ac.uk

Department of Psychological Sciences, Institute of Psychology, Health and Society, University of Liverpool, Liverpool, UK

International Research Centre for Investigative Psychology (IRCIP), University of Huddersfield, Huddersfield, UK 
ceasefire deals between the government and BH have failed continuously (Falayi, 2014). The viciousness of the organisation's modus operandi escalated even further on January, 2015 when they allegedly killed 2000 citizens in a single attack that lasted 4 days in and around Baga, a town on the border with Chad, (Mark, 2015) showing that the authorities are failing to get the BH crises under control. Understanding why this failure continues may enable law enforcement officials and the government to develop new strategies.

Despite numerous issues arising from the BH crisis, very little research was carried out during this crisis period. The limited research that has been conducted has been underpowered, probably due to participants being unwilling to voice options on BH and security forces (Bagheri, 2012). Critically, the relationship between the Nigeria Police and the public is one underpinned by fear and mistrust (Alemika, 1988, Carter and Marenin, 1977; Goldsmith, 2005; Jemibewon, 2000; Zumve, 2012) and, without an improvement of public confidence in the security forces, the likelihood of reaching an end to the security crisis is limited. This research is aimed at investigating public willingness to help the police during the $\mathrm{BH}$ crisis. Also, since some of the population may be unwilling to assist the police, understanding the role key moderators such as public perceptions of police effectiveness and individual differences between those that are willing to help and those who are not may indicate where exactly efforts need to be focused.

\section{Public Perceptions of Police Effectiveness}

The literature indicates that four variables have consistently been shown to affect attitudes towards the police; age (Sampson and Bartusch, 1998; Worrall, 1999), contact with the police (Smith et al., 1991; Worrall, 1999), neighbourhood (Jesilow and Meyer, 2001), and race (Reisig and Parks, 2000; Sampson and Bartusch, 1998), while other individual level and contextual variables have shown less consistent findings (see Brown and Reed Benedict, 2002). What is clear is that individual differences in perceptions of police effectiveness warrant further understanding, especially in the context in which they occur. This is largely because research suggests that police legitimacy is impacted by such perceptions; if people do not perceive the police as being able to be fair and helpful then they are less willing to help them in situations where public cooperation is needed as well as losing support for the decisions the police make (Tyler, 1997).

\section{Gender Differences}

There are significant differences between gender and confidence in the police. For example, Morris (2014) investigated public confidence in police among individuals across a total of 57 countries using individual level data from the 2005 to 2008 World Values Survey and found that females were more likely to have greater confidence in the police. Furthermore, females are also more likely to report crimes (Miles-Johnson, 2013). It may be that gender differences are shaped by personal contacts with the police, with males being more likely to have had previous face-to-face contact with the police than females (Eith and Durose, 2011) with previous studies showing that more direct experiences with police produce less positive opinion of the police (Dean, 1980; Correia et al., 1996; Resig and Parks, 2000; Yeo and Budd, 2000). However, as Schafer et al. (2003) highlight, findings around the nature of the relationship between gender and perceptions of the police have been inconsistent. There are also further issues with generalising studies due to the different gender roles and the associated socialisation processes that occur in between countries. For example, in Nigeria, it is males who are culturally expected to undertake the role of reporting criminal activity to the police (Ayodele and Aderinto, 2014), which differs from the cultural expectations of Westernised countries whereby it is common for females to report criminal activity to the police (Eith and Durose, 2011). It is therefore important to explore whether differences in gender occur in Nigeria to identify the groups that are more willing to cooperate with the police.

\section{Religious Differences}

Religious differences in perceptions of police effectiveness have been overlooked in previous research. However, in countries such as Nigeria, which has been rated as one of the most religious countries in the world (Ifeduba et al., 2013), they may have a significant impact on perception of effectiveness. Ever since independence, tensions have been rising between Muslims and Christians to the point that any activity relating to religion bears a significant risk (Anyadike, 2013; Chinwokwu, 2013; Ezeogu and Obi, 2013), and there are sharp divides between Muslims and Christians in Nigeria that reflect the socioeconomic inequalities (Langer and Ukiwo, 2008). It is therefore, reasonable to expect that religion influences perceptions of police and willingness to help the police. In post 9/11 based findings, Schildkraut's (2002) US-based research found that Muslims and non-Muslims have similar perceptions of the police's authority to carry out certain authoritative activities like "stop and search" of Muslims and Arabs across the country. Moreover, Sun et al., (2011) found that being an Arab Muslim was negatively associated with supporting police practises involving the detainment of suspects of terrorism without concrete evidence. Relevant research is still limited in scope and focus and it is contextdependent, hence any related results must be cautiously interpreted in the context of the BH outbreak. Past research cannot clearly inform how key demographics such as religion 
may affect public willingness to help and perceptions of police effectiveness in tackling the $\mathrm{BH}$ crisis.

\section{Residence Location Differences}

The influence of neighbourhood characteristics on public perceptions of the police has been observed to vary both between (Campbell and Schuman, 1972) and within communities (Thurman and Resig, 1996). Such differences, for example, have been even observed between neighbourhoods served by the same police force (Resig and Parks, 2000) suggesting that factors such as specific resident location have an important role in generating and sustaining perceptions of the police. Neighbourhood characteristics have been found to also mediate the effect of factors such as race on perceptions of the police (Schafer et al., 2003). Such factors are hence fruitful for further research, particularly in contexts where relevant research is scarce, as they may influence public perceptions of the police. Perceptions of the police may also be affected by crime and disorder problems within neighbourhoods, whether real or perceived. A large body of research has found that negative perceptions of the police tend to be provided by those residing in high-crime neighbourhoods (Parker et al., 1995; Resig and Parks, 2000; Sampson and Bartusch, 1998). Those who are fearful of crime within their neighbourhoods are also more likely to hold negative perceptions of the police (Smith et al., 1999).

Research that has been carried out in African countries such as Ghana (Tankebe, 2009), indicated that Western perceptions of police effectiveness differ directly from those in African public surveys. However, in Africa, there are stark differences with regarding the ethnic composition of samples (Langer and Ukiwo, 2008), which may influence perceptions of police effectiveness and willingness to help the police. It is therefore important, in being able to understand the relationship between the police and the public during the $\mathrm{BH}$ crises that research is carried out in that context rather than simply generalising the results from previous studies.

It was the objective of this study to ascertain whether the public is willing to help the police during the $\mathrm{BH}$ crisis and then to examine whether their perceptions of police effectiveness may mediate their willingness to help. Alongside this, the present study seeks to examine whether there are significant differences between gender, religion, and residence location in both perceived effectiveness and willingness to help. This is the first empirically tested survey of Nigerians regarding police's handling of the $\mathrm{BH}$ crisis and their willingness to help the police taking also into account whether participants live in the north where the crisis has spread and also investigating whether there are differences between gender and religions. Considering the recent burst of religious extremism and the respective terrorist attacks, it is important to gather information on key factors that may support the gathering of valuable intelligence and improve police practices and police relations with the public.

\section{Method}

\section{Participants}

An opportunity sample consisting of 200 individuals (110 males and 90 females) from the general public completed the survey in English, the official language of Nigeria. The participants ranged in age from 20 to 67 years $(M=32.48$; $S D=8.93)$. One hundred and fourteen participants $(57 \%)$ identified themselves as Christians and $86(43 \%)$ as Muslims. A total of $110(55 \%)$ participants were living in the north and 90 (45\%) were living in the south of the country. All participants below 18 years of age were exempted. Others excluded were those who showed fear or doubt about participating even after they had given their consent initially and e-mail addresses. The last category excluded was policemen. The research needed to find out perceptions of the public towards the police, which meant ordinary people outside the force, devoid of their perceptions of themselves. Of the 410 questionnaires distributed to the research participants, 200 were fully filled and returned. This amount represents a response rate of $49 \%$.

The distribution and collection process lasted approximately 9 weeks. The initially poor response rate forced the researchers to embark on a second recruitment phase until 200 completed responses were received.

\section{Measures}

\section{Willingness to Cooperate with the Police}

The six items used to operationalise willingness were adapted from past research in willingness to help and cooperate with the police based in African contexts (see e.g. Tankebe, 2009) and included (1) "I am not willing to report to the Police any suspicious criminal activity related to BH if I happen to be a witness", (2) "If I witness any criminal activity related to BH I will contact the Police", (3) "I am willing to give my full cooperation to the Nigerian Police at all times when they need it", (4) "I cannot cooperate with the Police with anything even if they approach me for help", (5) "Cooperating with the Nigerian Police should be everyone's priority at this difficult time", (6) "Cooperating with the Nigerian Police with their work is never my priority". Likert-type response set was used with responses ranging from 1 - strongly agree to 5 - strongly disagree (Cronbach's alpha $=0.91, M=16.02, S D=7.04)$. 


\section{Public Perceptions of Police Effectiveness}

The ten items used to operationalise police effectiveness were (1) "The Nigeria Police lack the resources needed to successfully win the war against Boko Haram", (2) "Police effectiveness during the Boko Haram uprising has been very high", (3) "The modus operandi of the Nigeria Police Force during the Boko Haram crisis has been unprofessional", (4) "The methods used by the Nigeria Police Force in handling the detained Boko Haram suspects in their custody is simply unprofessional", (5) "Police efforts in curbing the Boko Haram attacks are evidently ineffective", (6) "The counterterrorist mode of operations of the Nigeria Police amidst the Boko Haram wave of attacks is very professional", (7) "Boko Haram suspects in detention are treated fairly and in accordance with their fundamental rights as enshrined in the constitution", (8) "The Nigeria Police Force has adequate resources to handle the Boko Haram militants, (9) "The Nigeria Police Force is capable of bringing the Boko Haram crisis to an end, (10) "It is not prudent to assume that the Nigerian Police can actually bring the Boko Haram uprising to an end". Likert-type response set was used with responses ranging from 1 - strongly agree to 5 - strongly disagree (Cronbach's alpha $=0.70, M=36.83, S D=7.38$ ).

\section{Procedure}

This was an online survey that took place between October and December 2013. Face-to-face surveys were not considered since attacks from BH have spurred intense fear amongst the public and many may have declined or hesitated to participate due to perceived concerns of personal security. Travelling had also become very risky, particularly in northern Nigeria due to rise in highway robbery and sporadic political and religious unrests across the country, hence online surveys were used to ensure the security of all parties involved in the research. Participants were approached 6 months before the research began to be acquainted with the nature and purpose of the research. Accordingly, only those who agreed to the conditions under which the research was conducted and understanding its nature (for example being conducted for purely academic rather than intelligence purposes, being electronically based, keeping anonymity of respondents at all times) took part in the study. The researchers had to reach people from different parts of the country to ensure wide regional coverage; in fact an equal number of northern-southern participants was targeted. A significant amount of participants were introduced to the researchers through those already recruited; but each had to be independently re-briefed before agreeing to take part in the study.

An e-mail address on the yahoo website was specially created for the purposes of communication and exchange of information between the second author and the participants.
This was done to avoid using personal e-mail for the research to ensure that all correspondence and e-mail addresses of participants are wiped along with the e-mail account created for the study after the research was completed.

\section{Ethics}

Owing to issues of security involved, anonymity was guaranteed in order to avoid identification by anyone outside the research circle. Participants were also assured of medical, psychological, and security assistance in case any emergency ensues as a result of their participation in the study. Particularly, a temporary helpline was set for participants who may experience discomfort as a result of taking part in the study. Accordingly, a certified Nigeria-based medical practitioner has volunteered to provide support to participants who used the helpline. Ultimately none of the participants used this service. The e-mail account and survey account created for the research was erased immediately after the research has been completed and all participants were explained that no trace could link their anonymous responses back to them.

This research was conducted in accordance with BPS and APA research ethics guidelines. The research was fully discussed with potential participants, electronically-written informed consent was obtained after this discussion, and the study was conducted in accordance with the Declaration of Helsinki. Participants were also fully debriefed.

\section{Data Analysis: Factor Analysis and Structural Equation Modelling}

Firstly, an exploratory factor analysis of the willingness and effectiveness questionnaires was conducted, Kaiser's rule for maintenance of factors (i.e. eigenvalues in excess of 1) was used, and factor loadings were considered significant if loading at $>0.5$. Sampling adequacy was confirmed using the Kaiser-Meyer-Olkin measure (KMO), values between 0.5 and 0.7 being acceptable, and $0.7+$ being good to excellent (Hutcheson and Sofoniou 1999). To ensure sufficient correlations between items, Bartlett's test of sphericity was also used. Following the exploratory factor analysis, a confirmatory factor analysis of the latent questionnaire derived constructs was conducted, before analysing the full hypothesised model. For the testing of the hypothesised model, the maximum likelihood method was used. Multiple indices of model fit were calculated to ensure that the model represented a good fit of the data. As the standard $\chi^{2}$ test is overly sensitive to kurtosis and distribution, a normed $\chi^{2}$ value was also calculated $\left(\chi^{2} /\right.$ df). $\chi^{2} / \mathrm{df}$ values between 1 and 2 are indicative of a good model fit, between 2 and 5 an acceptable model fit (Carmines and McIver, 1981; Schumacker and Lomax, 2004). The standardised root mean residual (SRMR) absolute fit index was also used to assess model fit; values of 0 
represent perfect fit and values under 0.08 are representative of a good model fit. As well as discrepancy function methods, model fit was also estimated using the Tucker-Lewis index (TFI) for which values of 0.9 are considered a good fit. Additionally, the comparative fit index (CFI) and root mean square error of approximation (RMSEA) non-centrality based indices were also used to evaluate model fit (Bentler, 2007). CFI values equal to or greater than 0.95 and RMSEA values equal to or lower than 0.06 were used as cut-off points for good fit (Hu and Bentler, 1999), with RMSEA equal or lower to 0.08 being described as acceptable (Browne and Crudeck, 1993). In describing specific relationships within the structural model, unstandardised regression coefficients are reported within the text. In addition, bias corrected bootstrapping was utilised to obtain confidence intervals $\left(\mathrm{CI}_{95}\right)$ and associated $p$ values for all of the unstandardised regression coefficients reported.

\section{Results}

\section{Factor Analysis for Willingness to Report to Police}

An exploratory factor analysis of the six-item willingness questionnaire found the sampling adequacy to be excellent $(\mathrm{KMO}=0.92)$ and Bartlett's test of sphericity demonstrated that correlations between items were large enough $\left(\chi^{2}(10)=1139.20, p<0.001\right)$. The analysis produced a single factor solution, (eigenvalue $=4.83$, with all factor loadings $>0.85$ ).

\section{Factor Analysis for Effectiveness of Police Attitudes}

Since answers to the reversed-phrasing items were identical in terms of their means and variance to the positively phrased ones, FA only utilised the positive items to avoid running the same analysis twice. The exploratory factor analysis of the five-item effectiveness questionnaire found the sampling adequacy to be excellent $(\mathrm{KMO}=0.77)$ and Bartlett's test of sphericity demonstrated that correlations between items were large enough $\left(\chi^{2}(10)=251.38, p<0.001\right)$. The analysis produced a single factor solution, (eigenvalue $=2.16$, with all factor loadings $>0.59$ ).

\section{Structural Model}

Model fit The hypothesised structural model proved to be a good fit for the data. The discrepancy function measures and non-centrality based indices found the hypothesised structural model to be a good fit for the data $\left(\chi^{2} / \mathrm{df}=1.78\right.$; $\mathrm{SRMR}=0.05 ; \mathrm{TLI}=0.95, \mathrm{CFI}=0.96, \mathrm{RMSEA}=0.06$ )

Only religion of respondents was directly associated with perceptions of effectiveness of the police $(B=-0.39$,
$\mathrm{SE}=0.11, p<0.001)$, with Christian respondents believing the police to be less effective, although neither location of residence $(B=-0.03, \mathrm{SE}=0.09, p=0.74)$ or gender $(B=-0.05, \mathrm{SE}=0.09 p=0.61)$ significantly influencing perceptions of police effectiveness. Interestingly, religion was not directly associated with willingness to report to the police $(B=-0.06, \mathrm{SE}=0.19 p=0.76)$ although there was a trend towards those in the north being less willing to report to the police $(B=-0.30, \mathrm{SE}=0.17 p=0.08)$. Females were however significantly less willing to report to the police $(B=0.43, \mathrm{SE}=0.17 p=0.013)$.

As expected, there was a strong association between perceived effectiveness and willingness to report to the police with respondents who question the effectiveness of the police being less likely to be willing to report to them $(B=0.57, \mathrm{SE}=0.19 p=0.004)$. Further analysis of the indirect effects of demographic variables on willingness to report via effectiveness revealed the impact of religion on willingness to report was at least partially mediated by perceived effectiveness of the police ( $95 \% \mathrm{CI}-0.20$ to $-0.03, p=0.002$ ) (Fig. 1).

\section{Discussion}

The present study investigated public willingness to help the police during the $\mathrm{BH}$ crisis as a function of public perceptions of police effectiveness. Further to this, it also looked at individual differences with regards gender, religion, and residence location. The findings revealed a strong association between perceived effectiveness and willingness to report to the police with respondents who questioned the effectiveness of the police being less likely to be willing to report criminal activity. Whilst there were no significant gender differences in perceptions of police effectiveness, females were significantly less willing to report criminal activity in connection to the $\mathrm{BH}$ to the police. This is in contrast to findings of previous studies that showed that females hold more positive perceptions of the police (Morris, 2014) and are more willing to report crimes (Miles-Johnson, 2013).

The difference in findings are not surprising, and further highlight the importance of taking into account cultural differences discussed previously and the state of affairs in a country where terrorist attacks are so frequently committed. In Nigerian society, there are a number of factors that may account for the present study's findings. For example, it has been suggested that in this context women are more likely to succumb to fear (Ayodele and Aderinto, 2014). Therefore, the reason they may be less willing to report to the police is that they fear either becoming a victim themselves, or that the ramifications of helping the police will extend to those around them, including children. Furthermore, women may be more cautious due to the 


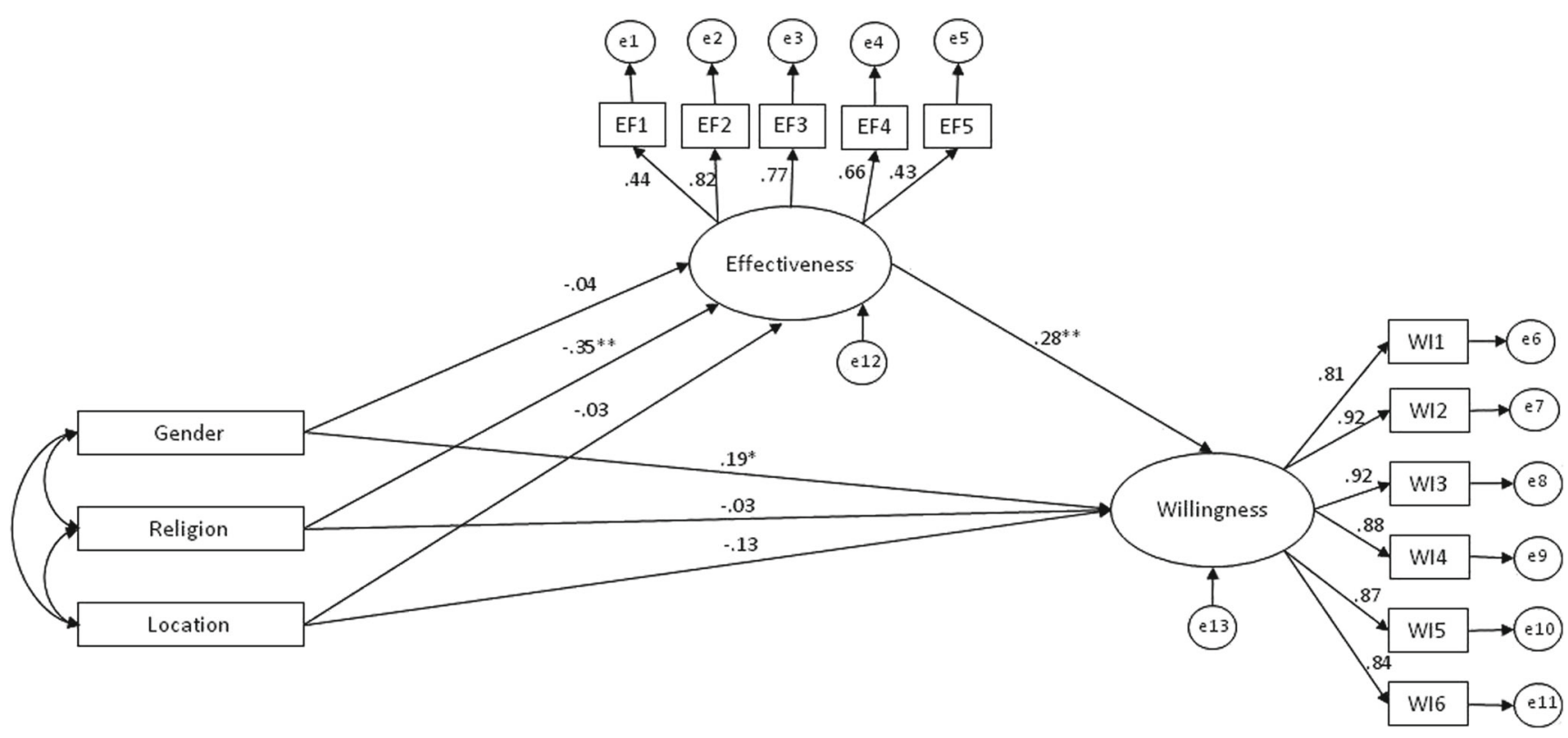

Note: all latent variable factor loadings significant at $\mathrm{p}<.001$

Fig. 1 Hypothesised model showing the effects of demographics on attitudes towards the effectiveness of police and willingness to report BH activities (values are standardised regression coefficients, $* p<0.05, * * p<0.01$

Note: all latent variable factor loadings significant at $p<0.001$

likelihood of having to provide testimony in court which may further the risks they are exposed.

This is the first empirical study to confirm that residents of various areas of Nigeria, irrespective of residence location or religion, are less likely to help the police when they see them as ineffective in handling the $\mathrm{BH}$ crisis. This finding is in line with previous findings regarding the association between willingness to help the police and perceptions of police effectiveness (Tankebe, 2009), although it is surprising as whilst resident location was not significantly associated with perceptions of effectiveness alone, there was a trend with those in the north being less willing to report. This may reflect that those in the north had more contact with the police (Smith et al., 1991; Worrall, 1999) throughout the $\mathrm{BH}$ crises, hence they may mistrust them (Alemika, 1988, Carter and Marenin, 1977; Goldsmith, 2005; Jemibewon, 2000; Zumve, 2012). However, the findings do not directly support the finding that those who reside in high-crime neighbourhoods (i.e. the northern areas) are more likely to hold negative perceptions of police effectiveness (Parker et al., 1995; Resig and Parks, 2000; Sampson and Bartusch, 1998). This indicates that there are further factors that may mediate that development of negative perceptions, such as severity of crime that may require further investigation.

Whilst the difference between Christian and Muslim respondents' willingness to help the police was not significant, Christians were more likely to perceive the police as less effective and subsequently less likely to report criminal activity to the police. This finding needs to be interpreted with caution though, as the north of Nigeria is dominated by the Muslim faith, and is the region in which $\mathrm{BH}$ has been primarily operating (CIA, 2014; Weeraratne, 2015; Murtada, 2013). This north/south divide makes it difficult to definitively state that religion alone caused the difference in perceptions of police effectiveness. It may be that religion interacts with other factors in influencing perceptions of the police. Religion's role in willingness to report a crime was mediated by perceived effectiveness of the police. Specifically, religion per se did not determine whether a crime will be reported but when the police were seen to be ineffective, one's religious belief had an effect with Christians considering the police significantly less effective.

A body of research has shown that general public perceptions hold the belief that the failure of the security agencies in stopping BH is attributed to a "weak" and uncommitted government (Alao et al., 2012; Epelle and Uranta, 2014; Oviasogie, 2013), hence public perceptions towards police effectiveness may at least partially reflect participants' perceptions of governmental initiative and ineffectiveness during the crisis. Future research should distinguish police from government and selectively access whether perceptions about the two core institutions handing the $\mathrm{BH}$ crisis are similar. In any case, the findings reveal that (Christian) women living in the north is the group that future research should be focussed on, bearing in mind that this study highlights that they are less likely to report $\mathrm{BH}$ related activity they may have witnessed. Also, this is the segment of the population whose trust must be regained 
to allow a better police-public collaboration during the ongoing $\mathrm{BH}$ crisis.

\section{Research Limitations and Challenges in Investigating Religious Extremism}

Psychological research is still developing in Nigerian institutions and most of the research on the police is focused around common issues like corruption and public perceptions of their modus operandi, and they relatively share similar results (Louw, 2002). It is clear therefore, that research is lacking in efforts adopted in the battle against sustainable peace and counter-terrorism today in Nigeria (Nwaka, 2000), although this is exactly what is currently needed. Previous research discussed in this paper is mostly Europe or US-based, hence past research may not necessarily have accurate cross-cultural applicability in a completely different part of the world, which limits the validity of comparisons. However, key findings from past research have been used comparatively in this paper in the absence of any other African or Nigerian based research that tackles phenomena such as $\mathrm{BH}$.

The inherent difficulties in conducting research in this area means that longitudinal research would be problematic. The sample size of this study has also suffered in that it failed to represent a bigger proportion of the country although the researchers ensured to keep a balance in the distribution of demographic characteristics. Research had to be restricted to participants who were computer literate and had access to internet in their present locations (as of 2013, only an estimated $25.42 \%$ of Nigerians had access to the internet, Amaefule, 2013). These are obstacles that may have prevented other researchers from conducting research in religious extremism within a country where such a phenomenon rapidly grows.

Despite these challenges, the current research has proved to offer an invaluable insight to the rapidly growing phenomenon of religious extremism. Particularly, it highlighted the demographic sectors that may see less favourably how the police handles the $\mathrm{BH}$ crisis and be less willing to cooperate and report criminal activity. There is a desperate need for public-police collaboration in Nigeria to be encouraged to allow the efficient policing of the extremist threat from expanding further (Waters \& Brown, 2000; Moore, 1992; RDS, 2003; Tankebe, 2009; Tuch and Weitzer, 2005). The current research provides a starting point on where efforts should be focused to achieve such collaboration. It is important for similar research projects to be conducted in order to inform government initiatives on matters regarding future policies to defend extremism and community policing with an ultimate goal to sustain peace and stability.

\section{Compliance with Ethical Standards}

Funding This research received no specific grant from any funding agency in the public, commercial, or not-for-profit sectors.
Conflict of Interest The authors declare that they have no conflict of interest.

Ethical Approval This research was conducted in accordance with BPS and APA research ethics guidelines and approved by the University Research Ethics Committee.

Informed Consent Standard procedures for gaining informed consent were used, and participants were informed of their right to withdraw from the study at any point without having any obligation to explain their reasons for withdrawing. The data was collected online so participants could merely close their browser at any point if they wished to withdraw.

Open Access This article is distributed under the terms of the Creative Commons Attribution 4.0 International License (http:// creativecommons.org/licenses/by/4.0/), which permits unrestricted use, distribution, and reproduction in any medium, provided you give appropriate credit to the original author(s) and the source, provide a link to the Creative Commons license, and indicate if changes were made.

\section{References}

Agbiboa DE (2013) The ongoing campaign of terror in Nigeria: Boko Haram versus the state. International Journal of Security and Development 2:1-18

Akinloye, B. (2014). BH may link up with ISIS - Australian negotiator. Punch, Retrieved from http://www.punchng.com/news/bharammay-link-up-with-isis-australian-negotiator/

Alao CO, Alao O, Atere O (2012) Boko-Haram insurgence in Nigeria: the challenges and lessons. Singaporean Journal of Business Economics, and Management Studies 1:1-15

Alemika E (1988) Policing and perceptions of police in Nigeria. Police Studies: The International Review of Police Development 11:161-176

Amaefule, E. (2013). 32.5 Million Nigerians Access Internet via Telecoms Networks". Punch. Retrieved from http://www.punchng. $\mathrm{com} /$ business/32-5-million-nigerians-access-internet-via-telecomsnetworks/

Anyadike NO (2013) Boko Haram and national security challenges in Nigeria: causes and solutions. Journal of Economics and Sustainable Development 4:12-23

Ayodele JO, Aderinto AA (2014) Public confidence in the police and crime reporting practices of victims in Lagos, Nigeria: a mixed methods study. International Journal of Criminal Justice Sciences 9:46-63

Bagheri, E. (2012). A qualitative investigation of religion, gender role beliefs, and culture in the lives of a select group of Muslim men. (Unpublished doctoral dissertation). University of Iowa, USA

Bentler PM (2007) On tests and indices for evaluating structural models. Personal Individ Differ 42:825-829

Brown B, Reed Benedict W (2002) Perceptions of the police: Past findings, methodological issues, conceptual issues and policy implications. Policing: An International Journal of Police Strategies \& Management 25(3):543-580

Browne MW, Crudeck R (1993) Alternative ways of assessing model fit. In: Bollen KA, Long JS (eds) Testing structural equations models. Sage, Newbury Park

C. I. A (2014). The world factbook. Retrieved from https://www.cia.gov/ library/publications/the-world-factbook/geos/ni.html

Campbell, A., and Schuman, H. (1972) A comparison of black and white attitudes and experiences in the city. The end of innocence: a suburban reader, $97-110$

Carmines EG, McIver JP (1981) Analysing models with unobserved variables: analysis of covariance structures. In: Bohrnstedt GW, 
Borgatta EF (eds) Social measurement: current issues. Sage, Beverly Hills, pp 65-115

Carter M, Marenin O (1977) Police in the community: perceptions of a government agency in action in Nigeria. African Law Studies 15:9-28

Chinwokwu EC (2013) Terrorism and the dilemmas of combating the menace in Nigeria. International Journal of Humanities and Social Science 3:265-272

Chukwuma I, Philip O (2014) Terrorism and humanitarian crisis in Nigeria: insights from BH insurgency. Global Journal of HumanSocial Science Research 14:39-49

Correia ME, Reisig MD, Lovrich NP (1996) Public perceptions of state police: an analysis of individual-level and contextual variables. J Crim Just 24:17-28

Dean D (1980) Citizen ratings of the police: the difference contact makes. Law and Policy Quarterly 2:445-471

Eith, C., and Durose, M. R. (2011) Contacts between police and the public, 2008. Washington, DC

Epelle A, Uranta IB (2014) Political economy of violence: interpreting the Nigerian Boko Haram. Mediterranean Journal of Social Sciences 5:528-535

Ezeogu UA, Obi C (2013) The morality of suicide terrorism and Boko Haram challenges in Nigeria. UJAH UNIZIK Journal of Arts and Humanities 14:174-191

Falayi, K. (2014). Dateline of major BH attacks in Nigeria. Punch. Retrieved from http://www.punchng.com/news/dateline-of-majorboko-haram-attacks-in-nigeria

Goldsmith A (2005) Police reform and the problem of trust. Theor Criminol 9:443-470

Hassan MB (2014) Boko Haram insurgency and the spate of insecurity in Nigeria: manifestation of governance crisis. Research on Humanities and Social Sciences 4:9-18

Hu L-t, Bentler PM (1999) Cutoff criteria for fit indexes in covariance structure analysis: conventional criteria versus new alternatives. Struct Equ Model Multidiscip J 6:1-55

Hutcheson G, Sofroniou N (1999) The multivariate social scientist. Sage, London

Ifeduba E, Oloyede B, Oni BO (2013) Contemporary Christian organizations in the development of mass communication in Nigeria: an exploratory study. New Media and Mass Communication 16:9-20

Jemibewon, D. (2000). The Nigerian experience. Paper given at the Conference on Crime and Policing in Transitional Societies, 30 August-1 September, South Africa

Jesilow P, Meyer JAF (2001) The effect of police misconduct on public attitudes: a quasi-experiment. J Crime Justice 24:109-121

Langer, A., and Ukiwo, U. (2008). Ethnicity, religion and the state in Ghana and Nigeria: perceptions from the street. Centre for Research on Inequality, Human Security and Ethnicity

Louw J (2002) Psychology, history, and society. South African Journal of Psychology 321:1-8

Mark, M. (2015) Boko Haram's deadliest massacre: 2000 feared dead in Nigeria. The Guardian. Retrieved from http:/www.theguardian.com/ world/2015/jan/09/boko-haram-deadliest-massacre-baga-nigeria

Miles-Johnson, T. (2013) LGBTI variations in crime reporting: how sexual identity influences decisions to call the cops. Sage Open, 1-15. DOI: $10.1177 / 2158244013490707$

Moore MH (1992) Problem-solving and community policing. Crime and Justice 15:99-158

Morris C (2014) An international study on public confidence in police. Police Pract Res Int J. doi:10.1080/15614263.2014.951935

Murtada A (2013) BH in Nigeria: its beginning, principles and activities in Nigeria. Bayero University, Kano
Nwaka G (2000) Higher education, the social sciences and national development in Nigeria. Prospects 303:373-385

Oviasogie F.O. (2013) State failure, terrorism and global security: an appraisal of the Boko Haram insurgency in northern Nigeria. Journal of Sustainable Society, 2.20-30

Parker, K.D., Onyekwuluje, A.B., and Murty, K.S. (1995). African Americans' attitudes toward the local police: a multivariate analysis. J Black Studies, 396-409

Reisig MD, Parks RB (2000) Experience, quality of life, and neighborhood context: a hierarchical analysis of satisfaction with police. Justice Q 17:607-630

Research Development and Statistics Directorate (RDS). (2003). Public perceptions of police accountability and decision making. Home Office report 38/03, UK. Research, Development and Statistics Directorate, London

Sampson RJ, Bartusch DJ (1998) Legal cynicism and (subcultural?) tolerance of deviance: the neighbourhood context of racial differences. Law \& Society Review 32:77-804

Schafer JA, Huebner BM, Bynum TS (2003) Citizen perceptions of police services: race, neighborhood context, and community policing. Police Quarterly 6:440-468

Schildkraut DJ (2002) The more things change... American identity and mass and elite responses to 9/11. Political Psychology 23:511-535

Schumacker RE, Lomax RG (2004) A beginner's guide to structural equation modelling, 2nd edn. Erlbaum, Mahwah

Smith DA, Graham N, Adams B (1991) Minorities and the police: attitudinal and behavioral questions. In: Lynch MJ, Patterson EB (eds) Race and criminal justice. Harrow and Heston Publishers, Albany, pp 22-35

Smith, S.K., Steadman, G.W., Minton, T.D. and Townsend, M. (Eds) (1999) Criminal victimization and perceptions of community safety in 12 cities, 1998, US Department of Justice, Bureau of Justice Assistance, Monograph NCJ 173940, Washington, DC

Sun IY, Wu Y, Poteyeva M (2011) Arab Americans' opinion on counterterrorism measures: the impact of race, ethnicity, and religion. Studies in Conflict \& Terrorism 34:540-555

Tankebe J (2009) Public cooperation with the police in Ghana: does procedural fairness matter? Criminology 47:1265-1293

Thurman QC, Reisig MD (1996) Community-oriented research in an era of community-oriented policing. Am Behav Sci 39:570-586

Tuch SA, Weitzer R (2005) Determinants of public satisfaction with the police. Police Quarterly 8:279-297

Tyler TR (1997) The psychology of legitimacy: a relational perspective on voluntary defence to authorities. Personal Soc Psychol Rev 1: 323-345

Waters, I., \& Brown, K. (2000). Police complaints and the complainants' experience. British Journal of Criminology, 40(4), 617-638

Weeraratne S (2015) Theorizing the expansion of the Boko Haram insurgency in Nigeria. Terrorism and Political Violence. doi:10.1080/ 09546553.2015.1005742

World Watch Monitor. (2017). Army recovers 24th Chibok kidnap victim. Retrieved from https://www.worldwatchmonitor.org/2016/10/ 4678875/

Worrall JL (1999) Public perceptions of police efficacy and image: the 'fuzziness' of support for the police. Am J Crim Justice 24:47-66

Yeo H, Budd T (2000) Policing and the public: findings from the 1998 British crime survey. Home Office, Research, Development and Statistics Directorate, London

Zumve SI (2012) Community policing in contemporary Nigeria: a synthesis of models. Journal of Educational and Social Research 2:132139 